\title{
PENGARUH MODEL PEMBELAJARAN CONTEXTUAL TEACHING AND LEARNING (CTL) TERHADAP KETERAMPILAN BERBICARA SISWA KELAS IV GUGUS 1 KECAMATAN WAWO
}

\author{
Astuti Mulyaningsi ${ }^{1)}$, Ida Bagus Kade Gunayasa ${ }^{2)}$, Moh. Irawan Zain ${ }^{3)}$ \\ 1), 2), 3) PGSD FKIP Universitas Mataram \\ *CorrespondingAuthor : astutia448@gmail.com
}

\begin{tabular}{l}
\hline ARTICLE INFO \\
\hline Article history \\
Received : October $28^{\text {st }}, 2021$ \\
Revised : November $29^{\text {st }}, 2021$ \\
Accepted : December $19^{\text {st }}, 2021$
\end{tabular}

Keywords:

CTL learning model, Speaking skills

\begin{abstract}
This study aims to determine the effect of the CTL learning model assisted by the Bima folklore on the speaking skills of the fourth grade students at Cluster 1 of Wawo District. The results of this study are expected to be theoretically and practically useful. This study was an experimental research with a quasi experimental design type nonequivalent control group design. The population of this study was all fourth grade students of Elementary School at cluster I of Wawo District academic year 2020/2021 with 86 students in total, consisting of SDN 2 Maria, SDN Inpres Ntori, SDN 3 Maria, and SDN Inpres Kombo. The sampling technique of this research was cluster random sampling type of probability sampling with grade 4 of SDN 3 Maria and SDN Inpres Kombo students as the sample. The data collection method in this study was a test of students' speaking skill used an assessment rubric (pretest-posttest). Data analysis was carried out by using the normality test, homogeneity test and hypothesis test used the polled variance of $t$-test formula. Hypothesis test at 5\% significant level produced $t_{\text {count }}=4.80$ while $t_{\text {table }}=1.687$, in other words $t_{\text {count }}>$ $t_{\text {table. }}$ Based on the test criteria, if $t_{-c o u n t}>t_{-t a b l e}$, then $H_{0}$ is rejected and $H_{a}$ is accepted. Therefore, it can be concluded that there is an effect of the CTL learning model assisted with the Bima folklore on the speaking skills of the fourth grade students at cluster I Wawo District in the academic year 2020/2021. Thus it can be stated that the learning model of Contextual Teaching And Learning (CTL) with the help of the Bima folklore can be applied in grade IV elementary school students to improve speaking skills.
\end{abstract}

\begin{abstract}
ABSTRAK
Penellitian ini bertujuan untuk mengetahui pengaruh model pembelajaran CTL berbantuan cerita rakyat Bima terhadap keterampilan berbicara siswa kelas IV Gugus 1 Kecamatan Wawo. Hasil penelitian ini diharapkan dapat bermanfaat secara teoritis maupun praktis. Jenis penelitian ini adalah penelitian eksperimen dengan desain quasi eksperimental design tipe nonequivalent control group design. Populasi penelitian ini adalah seluruh siswa kelas IV SDN Gugus I Kecamatan Wawo tahun pelajaran 2020/2021 dengan jumlah siswa 86 orang yang terdiri dari SDN 2 Maria, SDN Inpres Ntori, SDN 3 Maria, dan SDN Inpres Kombo. Teknik sampling penelitian ini adalah probability sampling tipe cluster random samplingdengan sampel kelas IV SDN 3 Maria dan kelas IV SDN Inpres Kombo. Metode pengumpulan data dalam penelitian ini adalah tes keterampilan berbicara siswa menggunakan rubrik penilaian (pretest-posttest).Analisis data dilakukan dengan uji normalitas, uji homogenitas dan uji hipotesis menggunakan rumus t-test polled varians. Uji hipotesis pada taraf signifikan $5 \%$
\end{abstract}


menghasilkant $t_{\text {hitung }}=4,80$ sedangkan $t_{\text {tabel }}=1,687$, dengan kata

lain, $t_{\text {hitung }}>t_{\text {tabel }}$. Berdasarkan kriteria pengujian yakni jika

$t_{\text {hitung }}>t_{\text {tabel }}$, maka $\mathrm{H}_{0}$ ditolak dan $\mathrm{H}_{\mathrm{a}}$ diterima. Oleh karena itu,

dapat disimpulkan bahwa ada pengaruh model pembelajaran CTL

berbantuan cerita rakyat Bima terhadap keterampilan berbicara siswa

kelas IV Gugus Kecamatan Wawo tahun pelajaran 2020/2021.

Dengan demikian dapat dinyatakan bahwa model pembelajaran

Contextual Teaching And Learning (CTL) berbantuan cerita rakyat

Bima dapat diterapkan di siswa SD kelas IV untuk meningkatkan

keterampilan berbicara.

\section{A. PENDAHULUAN}

Bahasa memiliki peran penting bagi kehidupan manusia kirannya tidak perlu diragukan lagi. Bahasa dipergunakan untuk menjalankan segala aktivitas hidup manusia.Seperti penelitian, penyuluhan, bahkan untuk menyampaikan pikiran, pandangan serta perasaan. Bidang-bidang seperti ilmu pengetahuan, hukum, kedokteran, pilitik, pendidikan rupanya juga memerlukan peran bahasa.Karena hanya dengan bahasa manusia mampu mengkomunikasikan segala hal. Bahasa mungkin bukan satu-satunya alat komunikasi manusia, selain dikenal isyarat, aneka simbol, kode, bunyi, semua itu akan bermakna setelah diterjemahkan kedalam bahasa manusia (Tarigan, 2008; Hamdini et al, 2021). Oleh karena itu, tidaklah berlebihan bila bahasa disebut sebagai alat komunikasi terpenting bagi manusia.

Manusia merupakan makhluk sosial yang saling berinteraksi satu sama lain. Wujud interaksi tersebut dapat tercermin dalam bentuk komunikasi. Komunikasi digunakan untuk menyampaikan maksud tertentu dari seseorang kepada orang lain melalui bahasa, baik itu secara lisan, tulisan, maupun isyarat. Tanpa bahasa kita akan sulit untuk menyampaikan maksud ataupun tujuan kita kepada orang lain serta mengadakan hubungan dalam pergaulan sehari-hari (Musaddat, 2017; Aspiana et al, 2021).

Keterampilan berbahasa mencakup keterampilan mendengarkan, berbicara, membaca dan menulis.Keterampilan berbicara merupakan aktivitas berbahasa kedua yang dilakukan manusia dalam kehidupan berbahasa, yaitu setelah aktivitas mendengarkan. Keterampilan berbicara merupakan salah satu aspek keterampilan berbahasa yang sangat penting dimiliki, karena sebagai makhluk sosial, manusia berinteraksi, berkomunikasi dengan manusia lain menggunakan bahasa sebagai media (Husada, et.al., 2019). Pembelajaran bahasa Indonesia tidak hanya dapat diperoleh di sekolah, tetapi belajar bahasa juga dapat diperoleh dari keluarga, teman, maupun lingkungan sekitar kita.

Keterampilan berbicara sangat penting perannya dan perlu untuk diajarkan di sekolah-sekolah dalam upaya melahirkan generasi milenial yang cerdas dan kreatif. Dengan menguasai keterampilan berbicara, generasi ini akan mampu mengekspresikan pikiran dan perasaanya secara cerdas dan sesuai konteks dan situasi pada saat berbicara. Keterampilan berbicara juga akan mampu melahirkan generasi muda yang kritis karena mereka memiliki kemampuan untuk mengekspresikan gagasan, pikiran, atau perasaan kepada orang lain secara runtun dan sistematis.

Model pembelajaran Contextual Teaching And Learning atau CTL adalah suatu strategi pembelajaran yang menekankan kepada proses keterlibatan siswa secara penuh 
untuk menemukan materi yang dipelajari dan menghubungkannya dengan situasi kehidupan nyata, sehingga siswa didorong untuk dapat menerapkannya dalam kehidupan mereka (Nilasari et al, 2016; Marhaeni, et.al., 2013; Jumiatain et al, 2013). CTL sangat relevan dengan pembelajaran abad 21, dimana pembelajaran abad 21 merupakan pembelajaran yang mempersiapkan generasi abad 21 menuju kemajuan Teknologi dan Komunikasi (TIK) yang berkembang begitu cepat dan memiliki pengaruh terhadap berbagai aspek kehidupan termasuk pada proses belajar mengajar.

Model Pembelajaran CTL dirasa dapat mempengaruhi keterampilan berbicara, dikarenakan pembelajaran CTL memiliki keunggulan atau keunikan. Model pembelajaran CTL sangat penting untuk diterapkan seorang pendidik (guru) agar proses pembelajaran yang akan dilaksanakan dapat meningkatkan kemampuan berbicara dalam pelajaran bahasa Indonesia yang nantinya akan diimplementasikan dalam kehidupan sehari-hari. Model Pembelajaran CTL dapat memberikan pengalaman belajar yang berkesan karena dalam model ini erat kaitannya dengan pengalaman langsung oleh peserta didik dalam kehidupan sehari-hari. Sementara itu upaya untuk meningkatkan keterampilan berbicara siswa dan menciptakan pembelajaran kontekstual perlu adanya bantuan media pembelajancerita rakyat Bima. Cerita rakyat Bima adalah cerita yang berasal dari masyarakat Bima yang telah di warisi secara lisan di gunakan untuk memunculkan nilai kearifan lokal yang berupa nilai budaya dan pendidikan karakter.

Oleh karena itu, perlu dibuktikan dalam penelitian dengan judul: Pengaruh Model Pembelajaran CTL Berbantuan Cerita Rakyat Bima Terhadap Keterampilan Berbicara Kelas IV Gugus 1 Kecamatan Wawo.

\section{B. METODE PENELITIAN}

Penelitian ini merupakan penelitian eksperimen. Menurut Sugiyono (2015:107) penelitian eksperimen adalah penelitian yang digunakan untuk mencari pengaruh perlakuan tertentu terhadap yang lain dalam kondisi yang terkendali. Jenis penelitian eksperimen yang digunakan adalah Quasi Exsperimen Desain Tipe Nonequivalent Kontrol Group Design.Penelitian ini dilakukan terhadap dua kelas yakni kelas eksperimen dan kelas kontrol.Pada kelas eksperimen diberikan perlakuan berupa pembelajaran menggunakan model CTL sedangkan pada kelas kontrol pembelajaran dilakukan dengan model pembelajaran konvensional. Sampel dalam penelitian ini adalah siswa kelas IV SDN 3 Maria yang berjumlah 19 siswa dan siswa kelas IV SDN Inpres Kombo yang berjumlah 20 siswa tahun pelajaran 2020/2021.

Untuk memperoleh data yang diperlukan dalam penelitian ini dapat menggunakan metode penggumpulan data tes.Tes dalam penelitian ini dilakukan untuk mengukur keterampilan berbicara siswa dalam pembelajaran dengan menggunakanmodelCTL berbantuan cerita rakyat Bima.Tes yang digunakan dalam penelitian ini adalah adalah tes keterampilan berbicara khususnya bercerita pada Pretest dan posttest.

\section{HASIL DAN PEMBAHASAN}

Pada tahap awal, peneliti memberikan pre-test pada kelas eksperimen dan kelas kontrol dengan tujuan melihat kemampuan awal siswa dari masing-masing kelas.Tahap 
berikutnya adalah peneliti memberi perlakuan pada kelas eksperimen dengan menggunakan model pembelajaran CTL berbantuan cerita rakyat Bima dan pada kelas kontrol tidak diberikan perlakuan.Pada tahap akhir setelah pemberian perlakuan, peneliti memberikan post-test pada kelas eksperimen dan kelas kontrol dengan tujuan melihat perbandingan antara kelas yang diberikan perlakuan dengan kelas yang tidak diberikan perlakuan.Berikut data perbandingan hasil Pretest dan Post-testkelas eksperimen dan kontrol

Tabel 1. Data hasil Pretest dan Post-test

\begin{tabular}{cccccc}
\hline \multirow{2}{*}{ Kelompok } & Jumlah Siswa & Tes & $\begin{array}{c}\text { Nilai } \\
\text { Tertinggi }\end{array}$ & $\begin{array}{c}\text { Nilai } \\
\text { Terendah }\end{array}$ & Rata-rata \\
\hline Eksperimen & 19 & Pre-Test & 75 & 50 & 60,4 \\
\cline { 2 - 5 } & & Post-Test & 95 & 70 & 80,5 \\
\hline Kontrol & 20 & Pre-Test & 70 & 50 & 59 \\
\cline { 3 - 6 } & & Post-Test & 75 & 58 & 68,6 \\
& & & & & \\
& & &
\end{tabular}

Berdasarkan tabel 1 di atas, dapat dilihat bahwa kelas eksperimen yang berjumlah 19 orang memperoleh nilai pre-test tertinggi 75 dan terendah 50 dengan nilai rata-rata sebesar 60,4. Sedangkan nilai post-test pada kelas eksperimen memperoleh nilai tertinggi 95 dan nilai terendah 70 dengan nilai rata-rata sebesar 80,5. Selanjutnya untuk kelas kontrol yang berjumlah 20 orang memperoleh nilai pre-test tertinggi 70 dan terendah 50 dengan nilai rata-rata sebesar 59. Sedangkan nilai post-test pada kelas kontrol memperoleh nilai tertinggi 75 dan nilai terendah 58 dengan nilai rata-rata sebesar 68,6. Berdasarkan data di atas dapat diinterpretasikan dalam bentuk grafik sebagai berikut.

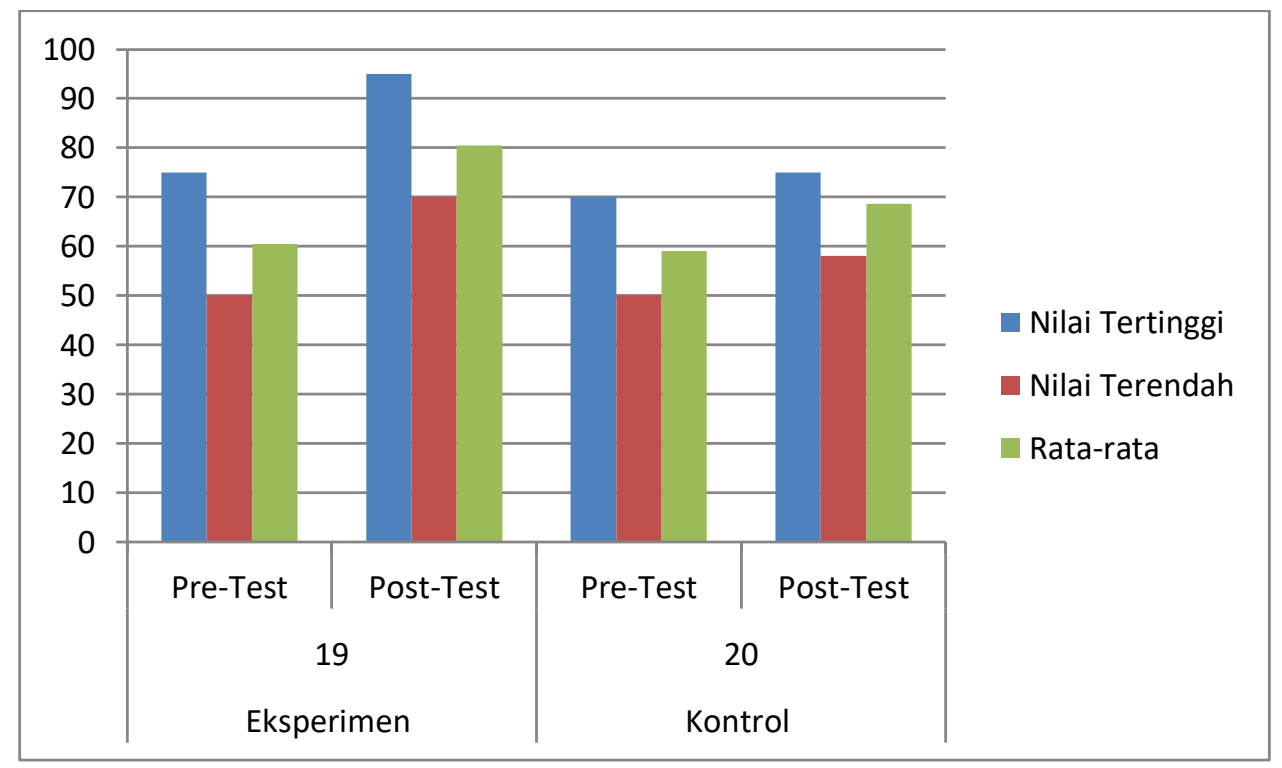

Gambar 1.Diagram Data Hasil Pre-test dan Post-test Siswa

Berdasarkan diagram di atas, terlihat bahwa hasil perkembangan keterampilan berbicara siswa kelas eksperimen setelah diberikan perlakuan (post-test) lebih baik dibandingkan dengan hasil perkembangan keterampilanberbicara siswa pada kelas kontrol 
(post-test) yang tidak diberikan perlakuan. Hal tersebut dapat dilihat dari perolehan nilai post-test pada kelas ekspeimen tertinggi 95 , terendah 70 dengan nilai rata-rata sebesar 80,5. Sedangkan nilai post-test pada kelas kontrol memperoleh nilai tertinggi 75 dan nilai terendah 58 dengan nilai rata-rata sebesar 68,6.

Setelah data keterampilan berbicara (pre-test dan post-test) siswa diperoleh, kemudian dilakukan uji normalitas data.Uji normalitas dilakukan terhadap data hasil pretest dan post-test kelas eksperimen dan kelas kontrol untuk mengetahui apakah data kedua kelas tersebut terdistribusi normal atau tidak normal. Uji normalitas data menggunakan rumusuji One Sample Kolmogorov Smirnov dengan menggunakan taraf signifikan 5\% dan derajat kebebasan $(\mathrm{dk} 1=\mathrm{n}-1)$ jika nilai $K \mathrm{~S}_{\text {hitung }}>\mathrm{KS} \mathrm{S}_{\text {tabel, }}$ maka data berdistribusi normal. Adapun ringkasan hasil uji normalitas data dapat dilihat pada tabel 2 berikut.

Tabel 2. Hasil Uji Normalitas Data Pre-test dan Post-test

kelas eksperimen dan kontrol

\begin{tabular}{clccc}
\hline Data & \multicolumn{1}{c}{ Kelas } & KS $_{\text {hitung }}$ & KS $_{\text {table }}$ & Kesimpulan \\
\hline \multirow{2}{*}{ Pre-test } & Kontrol & 0,1486 & 0,29407 & Terdistribusi normal \\
\cline { 2 - 5 } & Eksperimen & 0,1632 & 0,30142 & Terdistribusi normal \\
\hline \multirow{2}{*}{ Post-test } & Kontrol & 0,1485 & 0,29407 & Terdistribusi normal \\
\cline { 2 - 5 } & Eksperimen & 0,2589 & 0,30142 & Terdistribusi normal \\
\hline
\end{tabular}

Berdasarkan tabel 2 dapat diketahui bahwa semua data terdistribusi normal karena semua data pada kolom $\mathrm{KS}_{\text {hitung }}>\mathrm{KS}_{\text {tabel. }}$.Hasil perhitungan uji normalitas data pretest kelas kontrol, yakni $\mathrm{KS}_{\text {hitung }}=0,1486$ dimana $\mathrm{KS}_{\text {table }}=0,29407$. Nilai 0,1486<0,29407 oleh karena itu dapat disimpulkan bahwa data pretest hasil belajar kelas kontrol berdistribusi normal. Hasil perhitungan uji normalitas data pretesthasil belajar untuk kelas eksperimen, yakni $\mathrm{KS}_{\text {hirung }}=0,1632$ dimana $\mathrm{KS}_{\text {table }}=0,30142$ sehingga $0,1632<0,30142$. Oleh karena itu dapat disimpulkan bahwa data pretest hasil belajar kelas eksperimen berdistribusi normal. Dan hasil perhitungan uji normalitas data posttest hasil belajar untuk kelas kontrol, yakni $\mathrm{KS}_{\text {hitung }}=0,1485$ dimana $\mathrm{KS}_{\text {tabel}}=0,29407$ sehingga $0,1485<0,29407$ oleh karena itu dapat disimpulkan bahwa data posttest hasil belajar kelas kontrol berdistribusi normal. Hasil perhitungan uji normalitas data posttesthasil belajar untuk kelas eksperimen, yakni $\mathrm{KS}_{\text {hitung }}=0,2589$ dimana $\mathrm{KS}_{\text {tabel }}=0,30142$ sehingga $0,2589<0,30142$ oleh karena itu dapat disimpulkan bahwa data posttest hasil belajar kelas eksperimen berdistribusi normal.

Uji homogenitas digunakan untuk mengetahui apakah data kedua sampel penelitian memiliki varian yang homogen atau tidak, guna memenuhi uji prasyarat statistik parametris.Uji homogenitas dilakukan menggunakan uji analisis varian.Pada data keterampilan berbicara siswa ketika melaksanakan pre-test dan post-test di kelas eksperimen dan kelas kontrol. Data dikatakan bervarian homogen apabila Uji homogenitas menggunakan uji $\mathrm{F}$ dengan kriteria pengujian $d k 1=n_{a}-1 ; d k 2=n_{c}-1 ; \alpha=0,5$. Jika $F_{\text {hirung }}<\mathrm{F}_{\text {tabel }}$ maka data bersifat homogendisajikan dalam tabel 3 sebagai berikut: 
Tabel 3. Hasil Uji Homogentitas Data Posttest Kelas Kontrol dan Kelas Eksperimen

\begin{tabular}{|c|c|c|c|c|}
\hline Kelas & Varian & $F_{\text {hitung }}$ & $\mathbf{F}_{\text {tabel }}$ & Kesimpulan \\
\hline Kontrol & 42,98 & \multirow{2}{*}{1,911} & \multirow{2}{*}{2,20} & \multirow{2}{*}{ Data homogen } \\
\hline Eksperimen & 82,15 & & & \\
\hline
\end{tabular}

Nilai varian untuk kelas kontrol adalah42,98 dan nilai varian untuk kelas eksperimen adalah 82,15. Hal tersebut menjelaskan bahwa varian kelas eksperimen lebih tinggi dibandingkan dengan varian kelas kontrol sehingga yang menjadi dk1/dk pembilang adalah kelas eksperimen $(\mathrm{dk} 1=19)$ dan yang menjadi $\mathrm{dk} 2 / \mathrm{dk}$ penyebut adalah kelas kontrol $(\mathrm{dk} 2=20)$. Oleh karena itu, diperoleh nilai $F_{\text {hitung }}=1,911$ dan $F_{\text {tabel }}=2,20$ sehingga $F_{\text {hitung }}<$ $F_{\text {tabel }}$ dan dapat disimpulkan bahwa data bersifat homogen.

Uji hipotesis ini bertujuan untuk mengetahuipengaruh model pembelajaran CTL berbantuan cerita rakyat Bima terhadap keterampilan berbicara siswa kelas IV Gugus 1 Kecamatan Wawo. Berdasarkan hasil uji normalitas dan homogenitas data kelas kontrol dan kelas eksperimen yang berdistribusi normal dan data juga homogen, maka uji statistik yang digunakan adalah statistik parametrik dengan rumus $t$ poilled varians, karena jumlah sampel pada kelas kontrol dan kelas eksperimen tidak sama.

Tabel 4.Hasil Analisis Uji Hipotesis Data Posttest Kelas Kontrol dan Kelas Eksperimen

\begin{tabular}{lccccc}
\hline \multicolumn{1}{c}{ Kelas } & $\mathbf{N}$ & Rata-Rata & $\mathbf{S}^{\mathbf{2}}$ & $\boldsymbol{t}_{\text {hitung }}$ & $\boldsymbol{t}_{\text {tabel }}$ \\
\cline { 1 - 4 } Kontrol & 20 & 68,6 & 42,98 & \multirow{2}{*}{4,80} & \multirow{2}{*}{1,687} \\
\cline { 1 - 4 } Eksperimen & 19 & 80,5 & 82,15 & & \\
\cline { 1 - 4 }
\end{tabular}

Tabel 4 menunjukkan bahwa pada kelas kontrol dengan jumlah siswa 20 orang siswa mempunyai nilai rata-rata 68,6dan kelas eksperimen yang mempunyai 19 orang siswa memiliki nilai rata-rata sebesar 80,5. Nilai varian $\left(\mathrm{S}^{2}\right)$ dari kelas kontrol adalah 42,98dan nilai varian $\left(S^{2}\right)$ dari kelompok eksperimen adalah 82,15sehingga menghasilkan $t_{\text {hirung }}$ sebesar 4,80. Sedangkan pada taraf signifikansi 0,05 dan derajat kebebasan $(d k=n 1+$ $n 2-2$ ), nilai $t_{\text {tabel }}$ yang diperoleh adalah sebesar 1,687 sehingga $t_{\text {hirung }}>t_{\text {tabel }}$. Nilai $t_{\text {hirung }}=$ 4,80 dan nilait tabel $=1,687$. Kesimpulannya adalah ada pengaruh model pembelajaran CTL berbantuan cerita rakyat Bima terhadap keterampilan berbicara siswa kelas IV Gugus 1 Kecamatan Wawo.

Penelitian ini bertujuan untuk mengetahui pengaruh model pembelajaran CTL berbantuan cerita rakyat Bima terhadap keterampilan berbicara siswa kelas IV Gugus 1 Kecamatan Wawo.Berdasarkan hasil penelitian yang telah dilakukan, menunjukan bahwa model pembelajaran CTL berbantuan cerita rakyat Bima berpengaruh terhadap keterampilan berbicara siswa kelas IV Gugus 1 Kecamatan Wawo. Model CTL dapat memberikan pengalaman belajar yang berkesan karena dalam model ini erat kaitannya dengan pengalaman langsung oleh peserta didik dalam kehidupan sehari-hari. Sementara itu upaya untuk meningkatkan keterampilan berbicara siswa dan menciptakan pembelajaran kontekstual perlu adanya bantuan media pembelajan cerita rakyat Bima. Cerita rakyat Bima adalah cerita yang berasal dari masyarakat Bima yang telah di warisi secara lisan di gunakan untuk memunculkan nilai kearifan lokal yang berupa nilai budaya dan pendidikan karakter. 
Dalam penelitian ini perlakuan yang diberikan pada kelompok eksperimen adalah penggunaan model pembelajaran CTL berbantuan cerita rakyat Bima pada siswa eksperimen SDN 3 Maria. Kelompok kontrol pelaksanaan pembelajaran dengan tidak diberikan perlakuan berupa model pembelajaran CTL berbantuan cerita rakyat Bima dengan kata lain menggunakan pembelajaran konvensional.

Hasil analisis data menunjukkan bahwa nilai rata-rata kelas eksperimen lebih tinggi dari kelas kontrol. Nilai rata-rata kelas eksperime adalah 80,5 dan kelas kontrol adalah 68,6. Analisi data yang digunakan dalam penelitian ini adalah uji normalitas, uji homogenitasdan uji hipotesis.Uji normalitas menggunakan uji kolmogorov-smirnov dengan kriteria pengujian $\mathrm{dk}=\mathrm{n}$ dan $\alpha=0,05$ sehingga $k s_{\text {hitung }} k s_{\text {tabel }}$ maka data berdistribusi normal.Karena data sudah berdistribusi normal maka dapat dilakukan uji homogenitas menggunakan uji $\mathrm{F}$ dengan kriteria pengujian $d k 1=n_{a}-1 ; d k 2=n_{c}-1 ; \alpha=$ 0,5 sehingga menghasilkan $F_{\text {hirung }}<\mathrm{F}_{\text {tabel }}$ maka data bersifat homogen.

Berdasarkan hasil analisis data dengan menggunakan hasil uji $t$ poilled varians dengan menggunakan taraf signifikansi 5\% dan derajat kebebasan $(d k=n 1+n 2-2)$ menunjukkan nilai $t_{\text {hirung }}>$ nilait ${ }_{\text {tabel }}$ pada taraf signifikan $5 \%$ maka Ha diterima dan Ho ditolak artinya terdapat pengaruh model pembelajaran CTL berbantuan cerita rakyat Bima terhadap keterampilan berbicara siswa kelas IV Gugus 1 Kecamatan Wawo. Hal ini menjadikan model pembelajaran CTL berbantuan cerita rakyat Bima dapat diterapkan di Sekolah Dasar kelas IV.

\section{PENUTUP}

\section{Kesimpulan}

Berdasarkan hasil penelitian, analisis data, dan pembahasan maka dapat disimpulkan bahwa hasil belajar yang di capai sebelum diberikan perlakuan kepada kedua kelompok sampel (pretest) lebih rendah dibandingkan dengan setelah diberikan perlakuan (prettest) sehingga dapat disimpulkan terdapat pengaruh yang positif dan signifikan dalam penerapan model pembelajaran CTL berbantuan cerita rakyat Bima terhadap keterampilan berbicara siswa kelas IV Gugus I Kecamatan Wawo.

Analisis uji $\mathrm{t}$ dua pihak diperoleh hasil 4,516 ( $\left.\mathrm{t}_{\text {hitung }}\right)>1,686\left(\mathrm{t}_{\text {tabel }}\right)$ pada taraf signifikansi 5\% yang berarti bahwa Ho ditolak dan Ha diterima dengan kesimpulan yaitu terdapat pengaruh yang positif dan signifikan antara model pembelajaran CTL berbantuan cerita rakyat Bima dengan keterampilan berbicara siswa kelas IV Gugus 1 Kecamatan Wawo. Hal ini menjadikan model pembelajaran CTL berbantuan cerita rakyat Bima dapat diterapkan di Sekolah Dasar kelas IV.

\section{Saran}

Dari hasil penenlitian yang diperoleh maka penenliti memeberikan saran sebagai berikut:

Dengan hasil penelitian ini, diharapkan sekolah dapat mendukung serta memfasilitasi guru untuk menggunakan model pembelajaran yang beragam agar pembelajaran dapat berlangsung dengan menarik sehingga dapat meberikan hasil belajar yang optimal kepada siswa. 
Dengan hasil penelitian ini, model pembelajaran CTL dapat dijadikan sebagai salah satu refrensi model pembelajaran yang digunakan guru dalam mengajaragar pembelajaran dapat berlangsung dengan menarik dan dapat meningkatkan motivasi siswa dalam belajar.

Hasil penelitian ini diharapkan dapat diajukan sebagai acuan dalam penelitian selanjutnya, penelitian ini bukan hanya dijadikan sebagai referensi dalam melakukan penelitian, namun diharapkan dilakukan dengan materi yang berbeda dan tempat yang berbeda dan diharapkan dapat dikembangkan lagi menjadi lebih sempurna.

\section{DAFTAR PUSTAKA}

Aspiana, A., Gunayasa, I. B. K., \& Tahir, M. . (2021). Pengaruh Metode Story Telling Terhadap Kemampuan Berbicara Peserta Didik Gugus III Jonggat Tahun Pelajaran 2020/2021. Pendagogia: Jurnal Pendidikan Dasar, 1(3), 173-181.

Hamdini, M. W., Khairunnisa, K., \& Setiawan, H. (2021). Pengaruh Model Time Token Terhadap Keterampilan Berbicara Siswa Kelas IV SDN Prayitna Kecamatan Praya. Pendagogia: Jurnal Pendidikan Dasar, 1(2), 80-87.

Husada, A., Untari, M. F. A., \& Tsalatsa, A. N. (2019). Peningkatan Keterampilan Berbicara dengan Metode Bermain Peran Pada Siswa. Journal of Education Action Research, 3(2), 124-130.

Jumiatin, D. (2013). PENGARUH PEMBELAJARAN CONTEXTUAL TEACHING \& LEARNING (CTL) TERHADAP KETERAMPILAN BERBICARA DAN SOSIAL ANAK USIA DINI (Doctoral dissertation, Universitas Pendidikan Indonesia).

Marhaeni, A. B., Marhaeni, M. P. A. N., \& Sutama, M. P. P. I. M. (2013). Pengaruh Model Pembelajaran Kontekstual Berbasis Cerita Rakyat Terhadap Kemampuan Membaca Pemahaman Dan Minat Baca Pada Siswa Kelas V SD. (Doctoral dissertation, Ganesha University of Education).

Musaddat, S . (2017). Peningkatan Keterampilan Berbahasa Indonesia SD. Mataram: Agra Puji Press Mataram Lombok.

Nilasari, E., Djatmika, E. T., \& Santoso, A. (2016). Pengaruh penggunaan modul pembelajaran kontekstual terhadap hasil belajar siswa kelas V Sekolah Dasar. Jurnal Pendidikan: Teori, Penelitian, dan Pengembangan, 1(7), 1399-1404.

Sari, L. P. E., Ardana, I. K., \& Putra, D. K. N. S. (2016). Penerapan Metode Bercerita Berbantuan Media Gambar Berseri Untuk Meningkatkan Kemampuan Berbicara Pada Anak Kelompok A1. Jurnal Pendidikan Anak Usia Dini Undiksha, 4(1).

Sugiyono. (2015). Model Penelitian Pendidikan pendekatan kuantitatif, kualitatif, dan $R \& D$.Bandung: Alfabeta.

Tarigan, Guntur H. (2008). Berbicara Sebagai Suatu Keterampilan Berbahasa. Bandung: Angkasa Bandung. 